\title{
Diversity, consumption dynamics and ethnomedical claims of traditional leafy vegetables consumed by a rural community in the KwaMbonambi area, northern KwaZulu-Natal, South Africa
}

\author{
N.C. MNCWANGO ${ }^{1}$, S. MAVENGAHAMA ${ }^{2}$, N.R. NTULI ${ }^{3}$, C.M. VAN JAARSVELD ${ }^{1, \varphi}$ \\ ${ }^{1}$ Department of Agriculture, University of Zululand. Private Bag X 1001, Kwa-Dlangezwa, 3886, South Africa. •email: vanjaarsveldc@unizulu.ac.za \\ ${ }^{2}$ Food Security and Safety Niche Area Research Group, Faculty of Natural and Agricultural Sciences, North West University. Private Bag X2046, \\ Mmabatho, 2735, South Africa \\ ${ }^{3}$ Department of Botany, University of Zululand. Private Bag X 1001, Kwa-Dlangezwa, 3886, South Africa
}

Manuscript received: 27 November 2019. Revision accepted: 24 February 2020.

\begin{abstract}
Mncwango NC, Mavengahama S, Ntuli NR, van Jaarsveld CM. 2020. Diversity, consumption dynamics and ethnomedical claims of traditional leafy vegetables consumed by a rural community in the KwaMbonambi area, northern KwaZulu-Natal, South Africa. Biodiversitas 21: 1201-1207. Traditional leafy vegetables (TLVs) are mostly wild and informally-domesticated edible plant species. Their nutritious leaves, shoot tips, flowers and fruits are consumed as vegetables, particularly by rural communities in Africa. However, their consumption and cultivation are still marginal. This study aimed to identify the most preferred TLVs, as well as factors that affect the consumption and cultivation of these species. A questionnaire was administered among 100 respondents to record the preferred TLVs; the reason (s) for preference; consumption frequency; and constraints towards consumption of these vegetable species. This study recorded a total of 18 TLVs that belong to 14 genera and 11 families. Among these, Amaranthus hybridus, A. spinosus, A. thunbergii, Bidens biternata and Corchorus olitorius were the most preferred species. Vegetables were preferred primarily based on the taste; where most people ate them once a week when they are available. The major TLV consumption constraints were seasonal availability and low shelf life. A decline in the availability of TLVs was primarily caused by drought. Regardless of the observed decline, only $23 \%$ of respondents practiced informal cultivation of Amaranthus species. Bidens pilosa, Momordica balsamina, and Corchorus olitorius vegetable species were also known to possess some medicinal values. Future research on improving taste, increasing edible plant parts and elongating shelf life for preferred TLVs, is a necessity.
\end{abstract}

Keywords: Amaranthus species, Bidens biternata, Corchorus olitorius, edible weed, food security

\section{INTRODUCTION}

Traditional leafy vegetables (TLVs) are endemic or indigenized plant species that have become part of the culinary cultures of many indigenous groups worldwide and whose different plant parts are consumed as vegetables (Molina et al. 2014). Such plants can serve both for food and medicinal purposes (Njume et al. 2014). Consumed plant parts include tender or mature stems, leaves, roots, flowers as well as immature and mature fruits (Jansen van Rensburg et al. 2007; Ntuli 2013). TLVs are generally consumed as a relish with staple foods such as maize meal, ugali, fufu and nsima (Matenge 2011; Mavengahama 2013).

Most TLVs grow during warm and wet seasons (Langat 2014), while others grow year-round in wet areas (Lewu and Mavengahama 2010; Ntuli 2013). They can either be collected from the wild or are cultivated (Molina et al. 2014). Large quantities of various TLVs normally grow as weeds among other field crops in cultivated lands (Nkomo and Kambizi 2009; Langat 2014). They also occur naturally as weeds in grasslands, forests, along the roads and footpaths (Ntuli 2013). Traditional leafy vegetables are normally collected by females being assisted by children (Ngone et al. 2016). As a result, in most cases, the knowledge of TLVs tends to be female domain (Ntuli 2013; Langat 2014; Chakravarty et al. 2016).

The consumption of TLVs is common while their cultivation is very rare compared to fully domesticated species (Lewu and Mavengahama 2010; Tumwet et al. 2014). Preferences and gender differences (Vorster et al. 2007), unfamiliar taste (Mampholo et al. 2016), small leaf size (Mavengahama 2013), low shelf life and seasonal availability of the TLVs (Mampholo et al. 2016) have all contributed to the decline in their consumption. In addition, most TLVs are regarded as weeds, food for the poor (Jansen van Rensburg et al. 2014); woman's food (Nkomo and Kambizi 2009); and old-fashioned by young and urban people (Njume et al 2014; Van der Hoeven 2014; Konsam et al. 2016). Seeds of TLVs are also associated with dormancy which results in low germination and the young plants are susceptible to bolting which results in low yield (Mavengahama 2013).

Considering the potential of TLVs as a source of nourishment, there is a need to change the perception of particularly young and urban people regarding these crops (Lewu and Mavengahama 2010). There is also a need to select and breed for enhanced palatability (Ntuli 2013), tolerance to low winter temperatures to overcome seasonal availability as well as finding ways to produce high-quality 
seeds (Njume et al. 2014). Therefore, the aim of this study was to identify the most preferred TLV species in KwaMbonambi, as well as factors that affect consumption and cultivation of these species.

\section{MATERIALS AND METHODS}

The survey was conducted at the Bhubhubhu, Ekusayeni, Mboholo and Msunduze villages of KwaMbonambi area $\left(28^{\circ} 37^{\prime} \mathrm{S} ; 32^{\circ} 04^{\prime} \mathrm{E}\right)$, of the King Cetshwayo District, northern KwaZulu-Natal Province, South Africa. The Kwambonambi area is among those that are still challenged by hunger, malnutrition, diseases and rural poverty.

Data were collected by means of a questionnaire which was compiled in English but administered in isiZulu. A pre-tested, structured questionnaire was administered randomly to 25 homesteads in each of four villages giving a total of 100 respondents. The respondents were sampled from a population of 2872 people (Statistics South Africa, 2011). The study area was selected purposively based on project objectives but the selection of respondents was based on simple random sampling. The sample size was determined using Raosoft sample size calculator (Raosoft 2004). For the given population of 2872 people, the recommended sample size was 96 respondents based on a $95 \%$ confidence and $10 \%$ margin of error. 100 respondents were thus used in this study.

Prior to interview engagement, the purpose and nature of the study were explained to respondents and a written consent form was signed thereafter. Ethical clearance was obtained from the university ethics office and community entry protocols were observed. Selection of households was done using simple random sampling. Once the household was selected, the respondent was selected using purposive sampling in that an elderly and/or knowledgeable individual was interviewed. Both male and female respondents were grouped according to age in the following age ranges: young-age (18-34 years); middleage (35-54 years); and old-age (55 years and above).

During the survey, respondents listed the TLVs that they preferred with reasons. Information on habitat, season of collection, type of habitat from which they were collected, who collected them, plant parts consumed as well as their consumption frequency were recorded. The other sourced information included various staple foods which were accompanied by the TLVs. Information on TLV quantities and cultivation status was also documented. Propagation methods, other uses apart from consumption as well as constraints towards their consumption were recorded. Voucher specimens were prepared from identified leafy vegetables and housed at the University of Zululand Herbarium (ZULU).

Data were analyzed using IBM SPSS version 24 software (IBM Inc, Chicago, IL), where each questionnaire represented a case and the questions on the questionnaire represented variables and sub-variables. The simple descriptive statistics, such as frequencies and percentages were used to analyze the data.

\section{RESULTS AND DISCUSSION}

\section{Gender and age of respondents}

A total of 88 females and 12 males from different age groups were interviewed in this study (Table 1). In all villages, the majority of female respondents were in the middle-age group followed by old-aged groups. Females of these ages were predominantly found at home during the day as they take care of the young ones. Such findings correspond with the reports by Ntuli (2013) and Konsam et al. (2016), where females of this age were the major respondents.

\section{Preferred species}

Eighteen traditional leafy vegetable species were preferred according to this study. These species belong to fourteen genera and ten families (Table 2). The preferred species belonged to Amaranthaceae (4 species), Asteraceae (3 species), Aizoaceae (2 species), Brassicaceae (2 species), and Chenopodiaceae (2 species) families, in descending order. Consumption of species within the above-mentioned families concurs with similar studies conducted in northern KwaZulu-Natal (Ntuli 2013) and other rural areas of South Africa (Jansen van Rensburg et al. 2007; Njume et al. 2014). The Acanthaceae, Cucurbitaceae, Solanaceae, Tiliaceae, and Zygophyllaceae families were represented by only one species each.

Local taxonomy of these vegetables was predominantly one name per species, except for four out of eighteen documented species with more than one name. These results contradict the reports by Lewu and Mavengahama (2010), who reported a wide variation in local taxonomy of leafy vegetable species in northern KwaZulu-Natal. However, this minimum diversity in local naming might be a result of the relatively small area surveyed in the current study compared to the relatively large area surveyed by Lewu and Mavengahama (2010).

Table 1. Gender and age of respondents from four villages in the study area, KwaMbonambi area, northern KwaZulu-Natal, South Africa

\begin{tabular}{llcc}
\hline Villages & Age group & Males & Females \\
\hline Bhubhubhu & Young-age & 0 & 3 \\
& Middle age & 1 & 9 \\
\multirow{3}{*}{ Mboholo } & Old age & 4 & 8 \\
& Young-age & 0 & 4 \\
& Middle age & 1 & 11 \\
Msunduze & Old age & 1 & 8 \\
& Young-age & 0 & 1 \\
\multirow{3}{*}{ Ekusayeni } & Middle age & 2 & 14 \\
& Old age & 0 & 8 \\
\multirow{3}{*}{ Total number of } & Young-age & 0 & 3 \\
respondents & Middle age & 2 & 12 \\
& Old age & 1 & 7 \\
& & 12 & 88
\end{tabular}

respondents

Note: Age group: Young age, 18-34 years; Middle age, 35-54; Old age $>55$ years 
Table 2. Taxonomy, percentage of respondents preferring each traditional leafy vegetable, edible plant part (s), place and period of collection $(\mathrm{n}=100)$ in the KwaMbonambi area, northern KwaZulu-Natal, South Africa

\begin{tabular}{|c|c|c|c|c|c|c|}
\hline Species name & Family name & IsiZulu name & $\begin{array}{l}\text { Percentage } \\
\text { and gender }\end{array}$ & $\begin{array}{c}\text { Edible } \\
\text { part (s) }\end{array}$ & Source & Season \\
\hline Alternanthera sessilis (L.) DC. & Amaranthaceae & iNtombiyaqhenya & $8(\mathrm{~F})$ & $\mathrm{L}$ & RB & YR \\
\hline Amaranthus hybridus L. & Amaranthaceae & iMbuya enkulu & $75(\mathrm{~F}, \mathrm{M})$ & L,ST & C, FR, G, SL & $\mathrm{S}$ \\
\hline Amaranthus spinosus $\mathrm{L}$. & Amaranthaceae & iMbuyabathwa & $90(\mathrm{~F}, \mathrm{M})$ & $\mathrm{L}, \mathrm{ST}$ & $\mathrm{C}, \mathrm{FR}, \mathrm{G}, \mathrm{SL}$ & $\mathrm{S}$ \\
\hline Amaranthus thunbergii Moq. & Amaranthaceae & iMbuya encane & $99(\mathrm{~F}, \mathrm{M})$ & $\mathrm{L}, \mathrm{ST}$ & $\mathrm{C}, \mathrm{FR}, \mathrm{G}, \mathrm{SL}$ & $\mathrm{S}$ \\
\hline Asystasia schimperi T. Anderson & Acanthaceae & iMbobela & $10(\mathrm{~F})$ & $\mathrm{L}$ & $\mathrm{C}, \mathrm{FR}$ & $\mathrm{S}, \mathrm{SP}$ \\
\hline $\begin{array}{l}\text { Bidens biternata (Lour.) Merr. } \\
\& \text { Sherff }\end{array}$ & Asteraceae & uQadolo omhlophe & $82(\mathrm{~F}, \mathrm{M})$ & $\mathrm{L}, \mathrm{ST}$ & C, FR, G & $\mathrm{S}$ \\
\hline Bidens pilosa $\mathrm{L}$. & Asteraceae & $\begin{array}{l}\text { uQadolo omnyama; } \\
\text { uCucuza }\end{array}$ & $25(\mathrm{M})$ & $\mathrm{L}, \mathrm{ST}$ & $\mathrm{C}, \mathrm{FR}, \mathrm{G}$ & YR \\
\hline Brassica carinata A. Braun & Brassicaceae & iKhop'shini & $32(\mathrm{~F})$ & $\mathrm{L}$ & $\mathrm{C}, \mathrm{G}$ & $\mathrm{S}, \mathrm{SP}$ \\
\hline Chenopodium album $\mathrm{L}$. & Chenopodiaceae & $\begin{array}{l}\text { iMbilikicane engababi; } \\
\text { isiDwaba sesalukazi }\end{array}$ & $35(\mathrm{~F}, \mathrm{M})$ & $\mathrm{L}, \mathrm{ST}$ & $\mathrm{C}, \mathrm{FR}$ & $\mathrm{S}$ \\
\hline Chenopodium murale $\mathrm{L}$. & Chenopodiaceae & iMbilikicane ebabayo & $22(\mathrm{~F})$ & $\mathrm{L}$ & $\mathrm{C}, \mathrm{FR}$ & $\mathrm{S}$ \\
\hline Corchorus olitorius L. & Tiliaceae & iGusha & $63(\mathrm{~F}, \mathrm{M})$ & $\mathrm{L}$ & $\mathrm{C}, \mathrm{G}$ & $\mathrm{S}$ \\
\hline Momordica balsamina $\mathrm{L}$. & Cucurbitaceae & Intshungu & $7(\mathrm{M})$ & $\mathrm{L}$ & $\mathrm{C}, \mathrm{FR}$ & $\mathrm{S}$ \\
\hline Sisymbrium thellungii $\mathrm{L}$. & Brassicaeae & IsiQange & $45(\mathrm{~F})$ & $\mathrm{L}$ & $\mathrm{C}, \mathrm{FR}$ & $\mathrm{S}$ \\
\hline Solanum retroflexum Dunal & Solanaceae & umSobo & $20(\mathrm{~F})$ & $\mathrm{L}$ & $\mathrm{C}, \mathrm{SL}, \mathrm{FR}$ & $\mathrm{S}$ \\
\hline Sonchus oleraceus L. & Asteraceae & iKlabeklabe & $4(\mathrm{M})$ & $\mathrm{L}$ & $\mathrm{C}, \mathrm{G}$ & $\mathrm{S}$ \\
\hline Tetragonia decumbens Mil & Aizoaceae & $\begin{array}{l}\text { uBhocobele; isKhakha } \\
\text { somkhovu; uThambisa; } \\
\text { uMaNtombela }\end{array}$ & $10(\mathrm{~F})$ & $\mathrm{L}$ & $\mathrm{C}, \mathrm{G}$ & $\mathrm{S}, \mathrm{SP}$ \\
\hline $\begin{array}{l}\text { Tetragonia tetragonioides } \\
\text { (Pallos) Kuntze }\end{array}$ & Aizoaceae & $\begin{array}{l}\text { isiPinashi samaNdiya; } \\
\text { isiPinashi seNtaba }\end{array}$ & $25(\mathrm{~F})$ & L,ST & $\mathrm{C}$ & $\mathrm{S}$ \\
\hline Tribulus terrestris L. & Zygophyllaceae & uNkunzana & $1(\mathrm{~F})$ & $\mathrm{L}$ & $\mathrm{G}$ & $\mathrm{S}, \mathrm{SP}$ \\
\hline
\end{tabular}

Note: Gender: F- female; M- male. Edible part (s): L- leaves; ST- shoot tips. Source (s): B- bush; C- cultivated land; FR- forest; RBriver bank; G- grassland; SL- shrubland. Season: S- summer; SP- spring; YR-year round

The most preferred species in descending order were: Amaranthus thunbergii, A. spinosus, Bidens biternata, A. hybridus, and Corchorus olitorius. These vegetables were earlier rated as the most popular TLVs in northern KwaZulu-Natal (Ntuli 2013). They were preferred by both females and males in the current study. In addition to above mentioned TLVs, females also favored Alternanthera sessilis, Asystasia schimperi, Brassica carinata, Chenopodium murale, Sisymbrium thellungii, Solanum retroflexum, Tetragonia decumbens, T. tetragonioides and Tribulus terrestris. The fact that females preferred more species than the men in the current study could be because they are more knowledgeable on TLVs. Middle aged females were the most knowledgeable on TLVs in studies in northern KwaZulu-Natal (Ntuli 2013) and India (Konsam et al. 2016). Sithole et al. (2011) and Ngone et al. (2016) also reported that females, in general, possess more knowledge of TLVs since they are actively involved in their collection and cooking.

In the current study, the bitter-tasting B. pilosa, $C$. murale, Sonchus oleraceus, and Momordica balsamina were mainly preferred by males as compared to females and the youth. A similar trend was documented in northern parts of South Africa where males appreciated bitter-tasting TLVs such as Cleome gynandra (Jansen van Rensburg et al. 2007). Njume et al. (2014) also reported the bittertasting B. pilosa are mostly appreciated by males.

Reasons for preference of the recorded species in this study varied and included taste, size of the consumed plant part, easy access, familiarity to the vegetable and ease of preparation. This concurs with Jansen van Rensburg et al. (2014) who reported that the use of specific TLV species is often influenced by factors such as availability, ease of preparation or collection, taste, consistency, and appearance. Almost $80 \%$ of respondents preferred these leafy vegetables because of taste (Figure 1) and above $60 \%$ of the respondents favored these vegetables as per their local availability and ease of preparation. The preferred taste and ubiquitous availability of several Amaranthus species in most parts of South Africa (Njume et al. 2014; Van der Hoeven 2014) might explain their high preference as leafy vegetables in the KwaMbonambi area. It could also be because they were preferred by both males and females in the current study. Amaranthus thunbergii was regarded as the tastiest leafy vegetable of all preferred species in the current study, in spite of its smaller leaves and scarcity compared to large-leaved and abundant A. spinosus and A. hybridus species. In Limpopo, a survey (Faber et al. 2007) showed that A. hybridus and A. thunbergii were the most commonly eaten TLVs that support the current study.

Good taste was also an important trait for selecting $C$. olitorius, T. decumbens and A. schimperi in the current study. However, some respondents complained about the low leaf yield of these three species which makes their collection difficult. Mavengahama (2013) pointed out that the tedious collection of TLVs with small leaves has a negative impact on their use, thus most people prefer commercial vegetables with bigger leaves. 


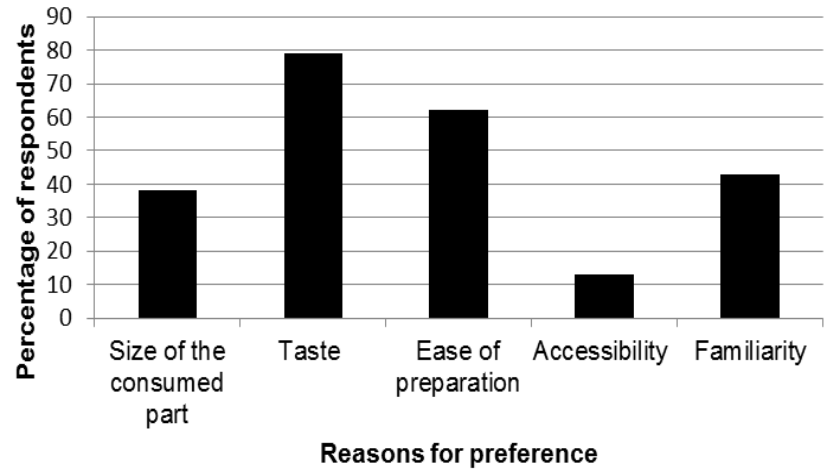

Figure 1. Reasons for preference of traditional leafy vegetables

Amaranthus spinosus was rated second for taste preference, but its spines make its collection difficult. Similarly, in Kenya, the vegetable use of A. spinosus is declining because of spines which restrict its harvest and sorting (Keding et al. 2007). Therefore, there is a need to select and breed for a broad-leaved $A$. thunbergii and spinefree A. spinosus.

The bitter-tasting $M$. balsamina and $B$. pilosa were mainly favored in the present study for therapeutic purposes. Further, the bad-smelling Chenopodium album and $C$. murale were mainly preferred for their soft texture. Species such as Brassica carinata, Sisymbrium thellungii, and Tetragonia tetragonioides were largely preferred in the current study because of their large consumed parts, appealing taste, and pleasant aroma.

Most respondents in the current study reported that they prefer to cook various TLVs together to overcome either the bitterness or toughness that is often associated with TLVs. Langat (2014) and Van der Hoeven (2014) also reported that TLVs are mixed to overcome bitterness. This practice of combining different TLV species during cooking results in the diversification of the diet, especially among the undernourished rural populations in most developing countries (Chauhan et al. 2014).

\section{Availability and harvesting}

Harvesting sites for TLVs varied from cultivated land, forest, grassland, riverbank, to shrubland (Table 2). The majority $(79 \%)$ of these vegetables were harvested among crops in cultivated land. The common occurrence of TLVs as weeds among cultivated crops was previously reported by Jansen van Rensburg et al. (2007) and Vorster et al. (2007).

The recorded TLVs were mostly harvested in summer. However, A. sessilis and B. pilosa were harvested yearround, while A. schimperi, B. carinata, T. decumbens, and Tribulus terrestris L. were available in spring. The reason for their year-round availability could result from drought resistance of B. pilosa (Faber et al. 2010) and distribution on riverbanks of $A$. sessilis where conditions are moist. Faber et al. (2010) also reported that B. pilosa can be harvested even in winter when other TLVs are no longer available. In the present study, $96 \%$ of TLVs were collected from intermittent wetlands; this could be the major reason for their high scarcity during the dry season (winter) when there are no rains in most parts of Southern Africa. There is, therefore, a need to breed for drought and cold resistant TLVs to overcome their seasonal availability shortfall.

Harvesting of traditional leafy vegetables was practiced mainly by females $(95 \%)$ rather than males $(5 \%)$ (Table 3 ). The majority of male respondents regarded the harvesting of TLVs as a female's job. This supports findings by Legwaila et al. (2011) and Njume et al. (2014) who reported that leafy vegetable harvesting in most developing countries is done by women and children. Respondents in the current study pointed out that both male and female youth do not harvest TLVs because their nails would become dirty. Also, most of young people regarded the harvesting of TLVs as an activity that lowers their dignity, yet they participated in their consumption.

The majority of respondents $(96 \%)$ noted a decline in the availability of TLVs in the area (Table 4). The major reason given for the decline was drought $(95 \%)$ which was also believed to restrict the consumption of various TLVs.

\section{Preparation and consumption}

According to respondents, traditional leafy vegetables were boiled first and then fried afterward (Table 3 ). In the case of bitter-tasting species such as Bidens pilosa, the cooking water was discarded and replaced with fresh water to reduce bitterness. Almost all (89\%) respondents preferred to serve various TLVs as a side dish to supplement pap, a staple dish. The minority served TLVs as a side dish to rice, bread, amaDumbe (Colocasia esculenta) and sweet potatoes (Table 3). The consumption of TLVs as a side food that accompanies pap in South Africa was also reported by Mavengahama (2013).

The survey showed that $41 \%$ of respondents consumed TLVs once a week (Table 3 ). The remaining portion of respondents (59\%) ate TLVs more than once a week, including $16 \%$ of the respondents who eat them daily. Some respondents claimed that frequent consumption of TLVs resulted in stomach problems. According to Orech et al. (2005), the leaves of TLVs contain significant amounts of phytochemical compounds such as alkaloids, phytotoxins, oxalates, flavonoids and glycosides that vary from species to species. These phytochemicals may accumulate and pose toxicity problems when leafy vegetables are consumed frequently and in large quantities (Matenge 2011; Tumwet et al. 2014).

The frequent collection and consumption (daily and three times a week) of TLVs in the current study might have been enhanced by low-income status of several ruralbased families. According to Taruvinga and Nengovhela (2015), the consumption of various TLVs is determined by the poverty status because those who earn more tend to rarely consume these TLVs. Also, the unavailability of TLVs could result in resource-poor families being exposed to hunger (Lewu and Mavengahama 2010). 
Table 3. Collection and consumption of preferred traditional leafy vegetables in KwaMbonambi area, northern KwaZulu-Natal, South Africa

\begin{tabular}{ll}
\hline Variable & $\begin{array}{l}\text { Proportion of } \\
\text { respondents }\end{array}$ \\
\hline Responsible collectors & 95 \\
Females & 5 \\
Males & \\
Consumption frequency & 41 \\
Once a week & 28 \\
Twice a week & 15 \\
Thrice a week & \\
Preparation methods & 0 \\
Boiling only & 0 \\
Frying only & 100 \\
Boiling and frying & 2 \\
amaDumbe & 2 \\
$\quad$ Sweet potatoes & \\
Consumption constraints & 95 \\
Seasonal availability & 12 \\
Taste & 81 \\
Low shelf life & 31 \\
Smaller size of the consumed part (s) & \\
\hline
\end{tabular}

Table 4. Accessibility, production system and production constraints of preferred traditional leafy vegetables in KwaMbonambi area, northern KwaZulu-Natal, South Africa

\begin{tabular}{lc}
\hline Variable & $\begin{array}{c}\text { Proportion of } \\
\text { respondents } \\
(\%)\end{array}$ \\
\hline Quantity of TLVs in the wild & 96 \\
Decreasing & 2 \\
Not changing & 2 \\
Unknown & \\
Reasons for decline in the wild & 95 \\
$\quad$ Drought & 4 \\
Overharvesting & 1 \\
Outbreak of invasive plants & \\
Do you cultivate TLVs? & 77 \\
$\quad$ No & 23 \\
$\quad$ Yes & \\
Production system used & 0 \\
$\quad$ Monocropping & 100 \\
Intercropping & \\
Seed sowing method & 100 \\
Broadcasting & 0 \\
$\quad$ Dribbling & \\
Type of fertilizer used & 100 \\
$\quad$ Organic & 0 \\
Inorganic & \\
Production constraints of TLVs & 55 \\
Lack of high-quality seeds & 6 \\
Seed unavailability & 27 \\
Sole growth of fully domesticated vegetables & 12 \\
Unawareness & \\
\hline
\end{tabular}

The major constraints toward TLV consumption in the current study were lack of year-round availability (95\%) and low shelf life $(81 \%)$ (Table 3). Lewu and
Mavengahama (2010) also recorded perishability as a major constraint with the storage, distribution and even the marketing of TLVs. The time-consuming collection and preparation of small-leaved vegetable species hampered their consumption in the current study area. Less traditional orientated females were reported to prefer consuming modern food which slowly shifts their interest from TLVs that require tedious collection and processing (Tumwet et al. 2014). The majority of respondents stated drought as the main reason for traditional leafy vegetable population decline in the study area. Similar findings were reported previously in KwaZulu-Natal, Mpumalanga and Limpopo provinces of South Africa (Vorster et al. 2008) and also in Western Kenya (Tumwet et al. 2014). Reports from communities of Manipur, northeast India, indicated that species disappearance in the wild results in loss of knowledge on the uses of these species (Konsam et al. 2016).

The current survey showed that $12 \%$ of the respondents did not want to consume TLV's because they did not like their taste (Table 3). Several studies reported on the poor taste of TLVs relative to that of commercial vegetables as a major reason for the decline in their consumption (Medoua and Oldewage-Theron 2014; Sowunmi 2015; Taruvinga and Nengovhela 2015; Mampholo et al. 2016; Ngone et al. 2016).

\section{Cultivation}

Of the 100 respondents in this survey, only 23 cultivated TLVs (Table 4). Even though the commercial value and role in food security of TLVs has been highlighted in other studies (Langat 2014; Van der Hoeven 2014; Konsam et al. 2016), their production is still very low in this area. Out of the diverse TLV species preferred in the study area, only amaranth species were cultivated as an intercrop with main cultivated crops. Several studies support this observation that in South Africa, many TLVs are still obtained by collecting rather than by cultivation and if cultivated the number of species is limited and cultivation occurs only on a small portion of land (Keding et al. 2007; Berinyuy and Fontem 2011; Njume et al. 2014; Tumwet et al. 2014; Ngone et al. 2016). Taruvinga and Nengovhela (2015) reported that the consumption of various TLVs was positively correlated to their production. Research regarding potential cultivation of traditional leafy vegetables such as Amaranthus hybridus and A. tricolor (Ribeiro et al. 2017), A. cruentus, Corchorus olitorius and Vigna unguiculata (Maseko et al. 2015; Mavengahama et al. 2016) has been initiated in South Africa.

When intercropping, TLV seeds harvested from the previous crop were broadcasted among summer crops after the addition of cattle manure in the current study. Intercropping of these leafy vegetables was also facilitated by their selective weeding by which TLV that are considered as weeds that emerged on their own are not removed during weeding. The effect of organic fertilizer was contradicting with some respondents indicating that yield is improved by its application while others claiming it has no effect. 
Table 5. List of traditional leafy vegetables used in traditional medicine in KwaMbonambi area, northern KwaZulu-Natal, South Africa

\begin{tabular}{lll}
\hline Botanical name & Traditional uses & Method of preparation \\
\hline Bidens pilosa & Heartburn, ear infection, kidney problems, stomach cramps, uterus cleaning & Eating raw and infusion \\
Momordica balsamina, & diabetes & Infusion \\
Solanum retroflexum & flu & Infusion \\
Corchorus olitorius & lack of water in the knees & Infusion \\
\hline
\end{tabular}

Half of respondents $(50 \%)$ identified the lack of highquality seeds as the major factor that restricted the cultivation of TLVs (Table 4). For instance, one of the respondents stated that she tried some of the amaranth seeds in her garden and none of them germinated thus she was discouraged from sowing them again. Some studies have also shown that the seeds from wild species are generally dormant which discourages their production (Etèka et al. 2010; Mavengahama 2013). Etèka et al. (2010) emphasized the importance of finding ways to establish seed systems for various TLVs species, which can lay a foundation for their commercial production.

In the current research, the fully domesticated leafy vegetables such as spinach and cabbage were cultivated more frequently than TLVs and thus more often consumed than TLVs. All the elderly respondents mentioned that they felt obligated to cultivate fully domesticated vegetables, even though they prefer TLVs.

Most people focused on planting crop species with a pleasant taste, which was frequently consumed, and had a high yield; and thus have good market value (Konsam et al. 2016). Therefore, there is a need to improve traits such as taste, growth, and yield of TLVs for future cultivation and commercialization practices.

\section{Medicinal uses}

In the current study, Bidens pilosa was reported to treat and manage heartburn, ear infection, kidney problems, stomach cramps as well as to clean the uterus in females after giving birth (Table 5). Similar findings on the consumption of $B$. pilosa leaves to reduce oesophageal cancer risks and to treat gastrointestinal disease were reported by Njume et al. (2014). Momordica balsamina, Solanum retroflexum and Corchorus olitorius were reported to manage diabetes, flu and lack of water in the knees, respectively, in the current study. Momordica balsamina was also used to manage hypertension at KwaMbonambi. Similar findings on M. balsamina were also reported by Mavengahama (2013).In Kenya, $S$. retroflexum is used as a remedy to prevent and manage hypertension, skin diseases and tooth decay (Langat 2014). Njume et al. (2014) regarded $C$. olitorius as a good source of vitamin A, especially in children. The bitter-tasting $B$. pilosa and $M$. balsamina were identified as having medicinal properties in the current study. Ntuli (2013) also reported that bitter TLVs are associated with medicinal use.

Older people of KwaMbonambi reported that the consumption of TLVs helped them to cope with hypertension. It was reported by Lewu and Afolayan (2009) that most TLVs are believed to have health benefits that are still highly exploited at household level. There is also a belief that in South Africa the rural populations consuming a traditional diet rich in green leafy vegetables are less affected by diseases such as coronary heart disease, hypertension, stroke and type 2 diabetes as compared to those that follow a modern urban diet (Matenge 2011).

To conclude, this study reported the preference of a wide variety of TLVs that are mostly collected from cultivated fields during spring and summer. Amaranthus hybridus, A. spinosus, A. thunbergii, Bidens biternata and Corchorus olitorius were the most preferred TLVs. The selection of these species was based primarily on taste and ease of preparation. The major constraints for their consumption were their lack of availability year-round and low shelf life. The study showed that TLVs are seldom cultivated and that cultivation was limited to Amaranthus species. The current study mentioned for the first time the use of rice, amaDumbe and sweet potatoes as the staple food accompanied by TLVs as a side dish.

\section{ACKNOWLEDGEMENTS}

National Research Foundation of South Africa for funding this research through grant number 98661.

\section{REFERENCES}

Berinyuy JE, Fontem DA. 2011. Evaluating post-harvest opportunities and constraints to utilization and marketing of African leafy vegetables in Cameroon. Afr J Food Agric Nutr Dev 11 (2): 4647-4663.

Chakravarty S, Bhutia KD, Suresh CP, Shukla G, Pala NA. 2016. A review on diversity, conservation and nutrition of wild edible fruits. $J$ Nat Appl Sci 8 (4): 2346-2353.

Chauhan D, Shrivastava AK, Patra S. 2014. Diversity of leafy vegetables used by tribal peoples of Chhattisgarh, India. Intl J Curr Microbiol Appl Sci 3 (4): 611-622.

Etèka CA, Ahohuendo BC, Ahoton LE, Dabadé SD, Ahanchédé A. 2010. Seeds' germination of four traditional leafy vegetables in Benin (LFT). Tropicultura 28 (3): 148-152.

Faber M, Oelofse A, Van Jaarsveld PJ, Wenhold F, Jansen van Rensburg WS. 2010. African leafy vegetables consumed by households in the Limpopo and KwaZulu-Natal provinces in South Africa. South Afr J Clin Nutr 23 (1): 30-38

Faber M, Van Jaarsveld PJ, Laubscher R. 2007. The contribution of darkgreen leafy vegetables to total micronutrient intake of two- to fiveyear-old children in a rural setting. Water SA 33 (3): 407-412.

Jansen van Rensburg WS, Cloete M, Gerrano AS, Adebola PO. 2014. Have you ever considered eating your weeds? Am J Plant Sci 5: 1110-1116. 
Jansen van Rensburg WS, van Averbeke W, Slabbert R, Faber M, Van Jaarsveld P, van Heerden I, Wenhold F, Oelofse A. 2007. African leafy vegetables in South Africa. Water SA 33 (3): 317-326.

Keding G, Weinberger K, Swai I, Mndiga H. 2007. Diversity, Traits and Use of Traditional Vegetables in Tanzania. AVRDC-The World Vegetable Center, Tainan, Taiwan, ROC.

Konsam S, Thongam B, Handique AK. 2016. Assessment of wild leafy vegetables traditionally consumed by the ethnic communities of Manipur, Northeast India. J Ethnobiol Ethnomed 12 (9): 1-15.

Langat PK. 2014. Association of Indigenous Knowledge with Nutrition, Health Claims and Consumption of Traditional African Leafy Vegetables: A Comparative Study of Agricultural and Pastora Communities of Narok South District. [Dissertation]. University of Nairobi, Nairobi. [Kenyan]

Legwaila GM, Mojeremane W, Madisa ME, Mmolotsi RM, Rampart M. 2011. Potential of traditional food plants in rural household food security in Botswana. Afr Crop Sci J 1 (3): 29-34.

Lewu FB, Afolayan AJ. 2009. Ethnomedicine in South Africa: The role of weedy species. Afr J Biotechnol 8 (6): 929-934.

Lewu FB, Mavengahama S. 2010. Wild vegetables in northern KwaZuluNatal, South Africa: Current status of production and research needs. Sci Res Essays 5 (20): 3044-3048.

Mampholo BM, Sivakumar D, Thompson AK. 2016. Maintaining overall quality of fresh traditional leafy vegetables of Southern Africa during the postharvest chain. Food Rev Intl 32 (4): 400-416.

Maseko I, Baletse YG, Nogemane N, Du Plooy CP, Mabhaudhi T. 2015. Growth, physiology and yield responses of Amaranthus cruentus Corchorus olitorius, and Vigna unguiculata to plant density under drip-irrigated commercial production. S Afr J Plant Soil 32 (2): 87-94.

Matenge STP. 2011. Utilisation of Traditional and Indigenous Foods in the North West Province of South Africa. [Dissertation]. North-West University, Potchefstroom. [South African]

Mavengahama S, De Clercq WP, McLachlan M. 2016. Effect of soil amendments on yield of wild okra (Corchorus olitorius) in northern KwaZulu-Natal, South Africa. S Afr J Plant Soil 33 (2): 153-156.

Mavengahama S. 2013. The contribution of Indigenous Vegetables to Food Security and Nutrition Within Selected Sites in South Africa. [Dissertation]. University of Stellenbosch, Stellenbosch. [South African]

Medoua GN, Oldewage-Theron WH. 2014. Effect of drying and cooking on nutritional value and antioxidant capacity of morogo (Amaranthus hybridus) a traditional leafy vegetable grown in South Africa. J Food Sci Technol 51 (4): 736-742.

Molina M, Tardío J, Aceituno-Mata L, Morales R. 2014. Weeds and food diversity: Natural yield assessment and future alternatives for traditionally consumed wild vegetables. J Ethnobiol 34 (1): 44-67.

Ngone AM, Monah NL, Mathias MA. 2016. Survey of wild vegetables in the Lebialem highlands of South Western Cameroon. J Plant Sci 4 (6): $172-184$
Njume C, Goduka NI, George G. 2014. Indigenous leafy vegetables (imifino, morogo, muhuro) in South Africa: A rich and unexplored source of nutrients and antioxidants. Afr J Biotechnol 13 (19): 19331942.

Nkomo M, Kambizi L. 2009. Effects of pre-chilling and temperature on seed germination of Corchorus olitorius L. (Tiliaceae) (Jew's Mallow), a wild leafy vegetable. Afr J Biotechnol 8 (6): 1078-1081.

Ntuli NR. 2013. A Survey of Traditional Leafy Vegetables and Studies of Genetic Diversity of Cucurbita landraces in Northern KwaZulu-Natal, South Africa. [Dissertation]. University of Zululand, Empangeni. [South African]

Orech FO, Akenga T, Ochora J, Friis H, Aagaard-Hansen J. 2005. Potential toxicity of some traditional leafy vegetables consumed in Nyang'oma Division, Western Kenya. Afr J Food Agric Nutr Develop 5 (1): 1-13.

Raosoft. 2004. Sample Size Calculator. Raosoft, Inc. http://www.raosoft.com/samplesize.html

Ribeiro JE, Pieterse PJ, Famba SI. 2017. Vegetative growth of Amaranthus hybridus and Amaranthus tricolor under different watering regimes in different seasons in southern Mozambique. S Afr J Plant Soil 2017: 1-10.

Sithole NTN, Thamaga-Chitja JM, Makanda I. 2011. The role of traditional leafy vegetables in household food security in rural KwaZulu-Natal. Indilinga-African J Indigen Knowl Syst 10 (2): 195209.

Sowunmi LI. 2015. Nutritional Value and cultivation requirements of Cleome gynandra L: A wild vegetable growing in the Eastern Cape province, South Africa. [Dissertation]. University of Fort Hare, East London. [South African]

Statistics South Africa. 2011. Census 2011. Department of Statistics, Pretoria. [South African]

Taruvinga A, Nengovhela R. 2015. Consumers' perceptions and consumption dynamics of African Leafy Vegetables (ALVs): Evidence from Feni Communal Area, Eastern Cape Province, South Africa. 2015 5th International Conference on Biomedical Engineering and Technology (ICBET 2015) 81 (16): 89-95.

Tumwet TN, Kang'ethe EK, Kogi-Makau W, Mwangi AM. 2014. Diversity and immune-boosting claims of some African indigenous leafy vegetables in Western Kenya. Afr J Food Agric Nutr Dev 14 (1): 8529-8544.

Van der Hoeven M. 2014. The effect of African Leafy Vegetables on The Alleviation of Micronutrient Deficiencies in School Children Residing in the North West Province of South Africa. [Dissertation]. University of North West, Potchefstroom. [South African]

Vorster IHJ, Jansen van Rensburg JWS, Venter SL. 2007. The importance of traditional leafy vegetables in South Africa. Afr J Food Agric Nutr Dev 7 (4): 1-13.

Vorster IHJ, Stevens JB, Steyn GJ. 2008. Production systems of traditional leafy vegetables: Challenges for research and extension. S Afr J Agric Exten 37: 85-96 